\title{
UJI AKTIVITAS ANTIOKSIDAN DARI EKSTRAK ETANOL DAUN Mimosa pudica Linn. MENGGUNAKAN METODE DPPH
}

\author{
Wulan $^{1)}$, Adithya Yudistira ${ }^{1)}$, Henki Rotinsulu ${ }^{1)}$ \\ ${ }^{1)}$ Program Studi Farmasi FMIPA UNSRAT Manado, 95115
}

\begin{abstract}
Antioxidant are compounds that can inhibit the oxidation rate of other molecules or neutralize free radicals. Putri Malu Leaf (Mimosa pudica Linn.) is not yet widely known as a medicinal plant. Through phytochemical screening, Mimosa pudica Linn. leaves known to have antioxidant compounds such as flavonoids, alkaloids, terpenoids, saponins and coumarin. This study aims to determine how much the antioxidant content in the extract of Mimosa pudica Linn. leaves using DPPH method with a concentration of $100 \mathrm{mg} / \mathrm{L}, 75 \mathrm{mg} / \mathrm{L}, 50 \mathrm{mg} / \mathrm{L}$ and $25 \mathrm{mg} / \mathrm{L}$ and Vitamin C as a positive control. Each sampel was made three repetitions of the test. The test uses a UV-Vis Spectrophotometer. The highest results were obtained from the concentration of $100 \mathrm{mg} / \mathrm{L}$ in the second repetition of $89.74 \%$. The highest average percentage of yield obtained is at a concentration of $100 \mathrm{mg} / \mathrm{L}$. Based on the result obtained from Mimosa pudica Linn. leaf extract seems like that the ethanol extract of Mimosa pudica Linn. leaves has high antioxidant activity.
\end{abstract}

Keywords: Antioxidant, DPPH, Mimosa pudica Linn.

\begin{abstract}
ABSTRAK
Antioksidan ialah senyawa yang mampu menghambat laju oksidasi molekul lain atau menetralisir radikal bebas. Daun Putri Malu (Mimosa pudica Linn.) belum dikenal luas sebagai tanaman obat.Melalui skrining fitokimia, daun Mimosa pudica Linn.diketahui memiliki senyawa antioksidan seperti flavonoid, alkaloid, terpenoid, saponin dan kumarin. Penelitian ini bertujuan untuk mengetahui seberapa besar kandungan antioksidan didalam ekstrak tanaman daun Mimosa pudica Linn.menggunakan metode DPPH dengan konsentrasi $100 \mathrm{mg} / \mathrm{L}, 75 \mathrm{mg} / \mathrm{L}, 50 \mathrm{mg} / \mathrm{L}$ dan $25 \mathrm{mg} / \mathrm{L}$ dan Vitamin C sebagai kontrol positif. Masing-masing sampel dibuat tiga kali pengulangan uji.Pengujian menggunakan alat Spektrofotometer UV-Vis. Terlihat hasil tertinggi diperoleh dari konsentrasi 100 $\mathrm{mg} / \mathrm{L}$ pada pengulangan ke-II yaitu sebesar $89,74 \%$. Rata-rata persentase hasil yang diperoleh tertinggi ialah pada konsentrasi $100 \mathrm{mg} / \mathrm{L}$. Berdasarkan hasil yang diperoleh dari ekstrak daun Mimosa pudica Linn.terlihat bahwa ekstrak etanol daun Mimosa pudica Linn. memiliki aktivitas antioksidan yang tinggi.
\end{abstract}

Kata Kunci : Antioksidan, DPPH,Mimosa pudica Linn. 


\section{PENDAHULUAN}

Antioksidan adalah senyawa yang mampu menghambat laju oksidasi molekul lain atau menetralisir radikal bebas (Fajriah, et al., 2007). Asupan antioksidan eksogen diperlukan, karena membantu mengembalikan keseimbangan tubuh dan memperlambat proses oksidasi senyawa radikal bebas. Antioksidan memberikan satu atau lebih atom hidrogen/elektron kepada radikal bebas sehingga senyawa radikal bebas dapat lebih stabil (Kuncahyo I and Sunardi, 2007).

Radikal bebas bersifat tidak stabil dan sangat reaktif sehingga cenderung bereaksi dengan molekul lainnya untuk mencapai kestabilan. Radikal dengan kereaktifan yang tinggi ini dapat memulai sebuah reaksi berantai dalan sekali pembentukannya sehingga menimbulkan senyawa yang tidak normal dan memulai reaksi berantai yang dapat merusak sel-sel penting dalam tubuh (Badarinath, et al., 2010).

Radikal bebas yang biasa digunakan sebagai model dalam mengukur daya penangkapan radikal bebas ialah 1,1-difenil-2-pikrilhidrazil (DPPH). Difenilpikrilhidrazil (DPPH) merupakan senyawa radikal bebas yang stabil. Nilai absorbansi DPPH berkisar antara 515-520 nm (Vanselow, 2007). Metode peredaman radikal bebas DPPH didasarkan pada reduksi dari larutan metanol radikal bebas DPPH yang berwarna oleh penghambatan radikal bebas. Ketika larutan DPPH yang berwarna ungu bertemu dengan bahan pendonor elektron maka DPPH akan tereduksi, menyebabkan warna ungu akan memudar dan digantikan warna kuning yang berasal dari gugus pikril (Prayoga, 2013).
Penggunaan senyawa antioksidan semakin berkembang baik untuk makanan maupun pengobatan seiring dengan bertambahnya pengetahuan tentang radikal bebas. Stress oksidatif merupakan keadaan yang tidak seimbang antara jumlah elektron radikal bebas dan antioksidan dalam tubuh (Trilaksani, 2003).

Antioksidan mampu melindungi tubuh terhadap kerusakan yang disebabkan senyawa oksigen reaktif, mampu menghambat terjadinya penyakit degeneratif seperti diabetes, kanker, inflamasi jaringan, kelainan imunitas, infark jantung dan penuaan dini (Midleton, et al., 2000). Tubuh manusia tidak mempunyai cadangan antioksidan dalam jumlah berlebih, sehingga jika terjadi paparan radikal bebas berlebih maka tubuh membutuhkan antioksidan eksogen (Rohdiana, 2001; Sunarni, 2005).

Atta-ur-Rahman

(2001), melaporkan bahwa senyawa-senyawa yang mempunyai potensi sebagai antioksidan umumnya merupakan senyawa flavonoid, fenolat dan alkaloid. Senyawa flavonoid dan fenolat bersifat antioksidan, antidiabetik, antikanker, antiseptik dan antiinflamasi. Sedangkan alkaloid mempunyai sifat antineoplastik yang juga ampuh menghambat pertumbuhan sel-sel kanker.

Tumbuhan di Indonesia yang mempunyai potensi sebagai antioksidan salah satunya ialah Mimosa pudica Linn.telah diketahui memiliki senyawa antioksidan seperti flavonoid, alkaloid, terpenoid, saponin dan kumarin (Meenaa, 2009; Ananthi, 2011). Ekstrak daun Mimosa pudica Linn. diketahui dapat meningkatkan enzim antioksidan seperti 
Superoxide Dismutase (SOD), Catalase, Glutathion Peroxidase (Brindha, 2009).

Mimosa pudica Linn. belum banyak diteliti dan belum ada penelitian tentang antioksidan, sehingga pada penelitian ini akan dilakukan uji aktivitas antioksidan dari ekstrak daun Mimosa pudica Linn. menggunakan metode DPPH dengan pelarut etanol p.a dengan konsentrasi 100, 75, 50 dan $25 \mathrm{mg} / \mathrm{L}$. Metode DPPH memberikan informasi reaktivitas sampel yang diuji dengan suatu radikal stabil. Penangkap radikal bebas menyebabkan warna yang sebanding dengan jumlah elektron yang diambil (Sasikumar, et al., 2009).

\section{TINJAUAN PUSTAKA}

\section{DEFINISI TANAMAN}

Mimosa pudica Linn. adalah perdu pendek anggota suku polong-polongan yang mudah dikenal karena daun-daunnya yang dapat secara cepat menutup/layu dengan sendirinya saat disentuh. Walaupun sejumlah suku polong-polongan dapat melakukan hal yang sama, Mimosa pudica Linn. bereaksi lebih cepat daripada jenis lainnya. Kelayuan ini bersifat sementara karena setelah beberapa menit keadaannya akan pulih seperti semula (Wikipedia, 2017).

\section{KANDUNGAN KIMIA TUMBUHAN Mimosa pudica Linn.}

\footnotetext{
Berdasarkan skrining fitokimia, Mimosa pudica Linn. mengandung senyawa-senyawa antioksidan seperti alkaloid, flavonoid, terpenoid, saponin dan kumarin. Ekstrak daun Mimosa pudica Linn. diketahui dapat meningkatkan enzim antioksidan seperti Superoxide Dismutase (SOD), Catalase dan Glutathion Peroxidase.
}

Tanaman Mimosa pudica Linn. bisa dimanfaatkan untuk mengatasi beberapa penyakit, namun tidak dianjurkan untuk ibu hamil.

METODE

\section{WAKTU DAN TEMPAT}

Penelitian ini dilaksanakan pada bulan Desember 2017 - Mei 2018. Tempat pelaksanaan dilakukan di laboratorium Farmakognosi Fitokimia, Laboratorium Analisis Farmasi dan Laboratorium Penelitian Program Studi Farmasi, Fakultas Matematika dan Ilmu Pengetahuan Alam, Universitas Sam Ratulangi.

\section{ALAT DAN BAHAN \\ ALAT}

Alat yang digunakan dalam penelitian ini ialah alat-alat gelas seperti baker glass $500 \mathrm{~mL}$, labu ukur $5 \mathrm{~mL}$, gelas ukur $1000 \mathrm{~mL}$, Erlenmeyer $500 \mathrm{~mL}$, cawan petri, cawan porselin, wadah botol, timbangan digital (AE ADAM), laboratorium blender, spektrofotometer UV-Vis (UV-1800), aluminium foil, incubator (ecocell), rotary evaporator (steroglass strike-300), spatula, pipet tetes, ayakan mesh 10 dan vortex.

\section{BAHAN}

Bahan yang digunakan dalam penelitian ini yaitu kertas saring, etanol 96\%, etanol p.a, serbuk DPPH, daun Mimosa pudica Linn. yang sudah tua dan serbuk vitamin C p.a sebagai kontrol positif (pembanding).

\section{BENTUK PENELITIAN}


Penelitian dilakukan dengan menggunakan metode DPPH dalam bentuk penelitian secara langsung.

\section{METODE PENELITIAN}

\section{Pengambilan Sampel}

Sampel diambil dikelurahan Lahendong, kecamatan Tomohon Selatan, Kota Tomohon, Provinsi Sulawesi Utara. Bagian yang digunakan dari tumbuhan ini ialah daun, sebanyak 1500gr.

\section{Preparasi Sampel}

Daun Mimosa pudica Linn. yang telah dipetik, dicuci, dikeringkan di udara terbuka dengan suhu ruangan. Setelah kering, daun dihaluskan dengan blender sampai menjadi serbuk dan diayak kemudian hasil ayakan disimpan pada wadah tertutup untuk dipakai pada perlakuan selanjutnya.

\section{Ekstraksi}

Sampel sebanyak 50 gram dimaserasi dengan pelarut etanol sebanyak $500 \mathrm{~mL}$ selama 3 kali 24 jam sambil sesekali diaduk. Hasil ekstraksi kemudian disaring untuk mendapatkan filtrat. Kemudian filtrat yang diperoleh setiap pergantian larutan digabungkan dan diuapkan menggunakan rotary evaporator hingga mendapatkan ekstrak kental dari daun Mimosa pudica Linn.

\section{Pembuatan Larutan Stok}

0,5 gram ekstrak daun Mimosa pudica Linn. dilarutkan dalam etanol p.a $10 \mathrm{~mL}$. Masing-masing konsentrasi 100, 75 , 50 dan $25 \mathrm{mg} / \mathrm{L}$, dihitung dengan menggunakan rumus pengenceran, yaitu :

$$
\mathbf{M}_{1} \cdot \mathbf{V}_{1}=\mathbf{M}_{2} \cdot \mathbf{V}_{2}
$$

Dari masing-masing hasil yang didapatkan dari hasil $\mathrm{V}_{1}$ dipipet dan ditambahkan etanol p.a hingga mencapai tanda batas $(5 \mathrm{~mL})$, kemudian dipindahkan ke dalam tabung reaksi dan ditutup dengan menggunakan aluminium foil untuk digunakan pada perlakuan selanjutnya.

\section{Pembuatan Larutan DPPH}

Cawan porselin ditimbang. Sebanyak 0,004 gr serbuk DPPH ditimbang dan dilarutkan dalam etanol p.a $10 \mathrm{~mL}$.

Selanjutnya larutan DPPH sebanyak 1,5 $\mathrm{mL}$ ditambahkan pada masing-masing konsentrasi larutan ekstrak daun Mimosa pudica Linn. dan divortex selama 2 detik. Berubahnya warna menjadi kuning menunjukkan bahwa, masingmasing konsentrasi menunjukkan efisiensi penangkal radikal bebas. Sampel diinkubasi selama 30 menit pada suhu $37^{\circ} \mathrm{C}$. Untuk mengetahui aktivitas dari penangkal radikal bebas tersebut, di uji pada spektrofotometer UV-Vis dengan panjang gelombang $517 \mathrm{~nm}$.

\section{Pengujian Larutan Kontrol DPPH dan Pengujian Sampel}

Larutan kontrol DPPH diuji pada spektrofotometer UV-Vis dengan panjang gelombang $517 \mathrm{~nm}$ sebagai absorbansi kontrol dalam pengujian ini.

Setelah pengujian sampel dan pengujian kontrol, dilanjutkan pada pengujian vitamin $\mathrm{C}$ p.a sebagai kontrol pembanding. Langkah pertama, cawan porselin ditimbang, vitamin $\mathrm{C}$ ditimbang sebanyak $10 \mathrm{mg}$ (0,01 gr). Kemudian, vitamin $\mathrm{C}$ p.a dilarutkan dalam etanol p.a sebanyak $10 \mathrm{~mL}$, buat larutan stok dengan konsentrasi 100, 75, 50 dan $25 \mathrm{mg} / \mathrm{L}$ dengan ditambahkan masing-masing 
larutan dengan etanol p.a mencapai tanda batas $(5 \mathrm{~mL})$, dengan pengulangan sebanyak 3 kali pada masing-masing konsentrasi.

Sampel vitamin C p.a diuji pada spektrofotometer UV-Vis dengan panjang gelombang $517 \mathrm{~nm}$.

\section{Pengujian Aktivitas Antioksidan dengan Metode DPPH}

sebanyak $0,5 \mathrm{~mL}$ ekstrak daun Mimosa pudica Linn. dengan konsentrasi 100, 75, 50 dan $25 \mathrm{mg} / \mathrm{L}$ ditambahkan masing-masing 1,5 mL larutan DPPH dan divortex selama 2 detik. Berubahnya warna ungu menjadi warna kuning menunjukkan efisiensi penangkal radikal bebas. Diukur absorbansi pada spektrofotometer UV-Vis dengan panjang gelombang $517 \mathrm{~nm}$ setelah diinkubasi selama 30 menit. Kemudian diamati perbandingannya dengan vitamin $\mathrm{C}$ p.a sebagai standar. Aktivitas penangkapan radikal bebas (persen inhibisi) dihitung sebagai persentase berkurangnya warna DPPH dengan menggunakan rumus :

\section{$\%$ inhibisi}

$=1-\frac{\text { absorbansi sampel }}{\text { absorbansi kontrol }} \times 100 \%$

\section{HASIL DAN PEMBAHASAN}

HASIL

\section{Hasil Pengujian Kontrol DPPH}

Dengan pengujian menggunakan alat Spektrofotometer UV-Vis dengan panjang gelombang $517 \mathrm{~nm}$, dan jarak panjang gelombang dimulai dari $480 \mathrm{~nm}$ sampai $600 \mathrm{~nm}$. Absorbansi kontrol DPPH didapatkan yaitu $0,838 \%$.

\section{Hasil Pengujian Sampel dan Vitamin C}

Pengujian menggunakan alat Spektrofotometer UV-Vis dimulai dari konsentrasi terendah, dengan 3 kali pengulangan pada setiap konsentrasi yang ada. Pengujian dibawah ini ialah pengujian sampel ekstrak etanol daun Mimosa pudica Linn. dan Vitamin C p.a sampai rata-rata dari hasil konsentrasi yang didapatkan pada pengulangan I hingga III.

\section{Pengujian}

Tabel I. Pengujian Sampel

\begin{tabular}{|c|c|c|c|c|}
\hline $\begin{array}{c}\text { Konse } \\
\text { ntrasi } \\
\text { Sampe } \\
1\end{array}$ & $\begin{array}{l}\text { Pengul } \\
\text { angan I } \\
\text { Sampel }\end{array}$ & $\begin{array}{l}\text { Pengul } \\
\text { angan } \\
\text { II } \\
\text { Sampel }\end{array}$ & $\begin{array}{l}\text { Pengul } \\
\text { angan } \\
\text { III } \\
\text { Sampel }\end{array}$ & $\begin{array}{c}\text { Rat } \\
\text { a- } \\
\text { Rat } \\
\text { a }\end{array}$ \\
\hline $\begin{array}{c}25 \\
\mathrm{mg} / \mathrm{L}\end{array}$ & $\begin{array}{c}84,61 \\
\%\end{array}$ & $\begin{array}{c}85,45 \\
\%\end{array}$ & $\begin{array}{c}82,11 \\
\%\end{array}$ & $\begin{array}{c}84,0 \\
5 \%\end{array}$ \\
\hline $\begin{array}{l}50 \\
\mathrm{mg} / \mathrm{L}\end{array}$ & $\begin{array}{c}82,82 \\
\%\end{array}$ & $\begin{array}{c}86,64 \\
\%\end{array}$ & $\begin{array}{c}87,83 \\
\%\end{array}$ & $\begin{array}{c}85,7 \\
6 \%\end{array}$ \\
\hline $\begin{array}{c}75 \\
\mathrm{mg} / \mathrm{L} \\
\end{array}$ & $\begin{array}{c}88,67 \\
\%\end{array}$ & $\begin{array}{c}88,67 \\
\%\end{array}$ & $85,8 \%$ & $\begin{array}{c}87,7 \\
1 \%\end{array}$ \\
\hline $\begin{array}{r}100 \\
\mathrm{mg} / \mathrm{L}\end{array}$ & $85,8 \%$ & $\begin{array}{c}89,74 \\
\%\end{array}$ & $\begin{array}{c}89,62 \\
\%\end{array}$ & $\begin{array}{c}88,3 \\
8 \%\end{array}$ \\
\hline
\end{tabular}

Tabel 2. Pengujian Sampel Ekstrak Etanol Vitamin C

\begin{tabular}{|c|c|c|c|c|}
\hline $\begin{array}{c}\text { Konse } \\
\text { ntrasi } \\
\begin{array}{c}\text { Vitami } \\
\text { n C }\end{array}\end{array}$ & $\begin{array}{c}\text { Pengul } \\
\text { angan I } \\
\text { Vit.C }\end{array}$ & $\begin{array}{c}\text { Pengul } \\
\text { angan } \\
\text { II } \\
\text { Vit.C }\end{array}$ & $\begin{array}{c}\text { Pengul } \\
\text { angan } \\
\text { III } \\
\text { Vit.C }\end{array}$ & $\begin{array}{c}\text { Rat } \\
\text { a- } \\
\text { Rat } \\
\text { a }\end{array}$ \\
\hline $\begin{array}{c}25 \\
\mathrm{mg} / \mathrm{L}\end{array}$ & $\begin{array}{c}89,38 \\
\%\end{array}$ & $\begin{array}{c}89,74 \\
\%\end{array}$ & $\begin{array}{c}88,55 \\
\%\end{array}$ & $\begin{array}{c}89,2 \\
2 \%\end{array}$ \\
\hline $\begin{array}{c}50 \\
\mathrm{mg} / \mathrm{L}\end{array}$ & $\begin{array}{c}86,76 \\
\%\end{array}$ & $\begin{array}{c}88,67 \\
\%\end{array}$ & $\begin{array}{c}88,07 \\
\%\end{array}$ & $\begin{array}{c}87,8 \\
3 \%\end{array}$ \\
\hline
\end{tabular}




\begin{tabular}{|c|c|c|c|c|}
\hline 75 & $\begin{array}{c}88,07 \\
\%\end{array}$ & $\begin{array}{c}89,03 \\
\%\end{array}$ & $89,5 \%$ & 88,8 \\
$\mathrm{mg} / \mathrm{L}$ & & & & $6 \%$ \\
\hline 100 & $\begin{array}{c}89,38 \\
\%\end{array}$ & $\begin{array}{c}89,27 \\
\%\end{array}$ & $\begin{array}{c}89,62 \\
\%\end{array}$ & 89,4 \\
$\mathrm{mg} / \mathrm{L}$ & & & & \\
\hline
\end{tabular}

Pengujian ini menggunakan alat Spektrofotometer UV-Vis dan pengujian dimulai dari konsentrasi terendah dari penelitian ini yaitu $25 \mathrm{mg} / \mathrm{L}$ hingga ke konsentrasi tertinggi dari penelitian ini yaitu $100 \mathrm{mg} / \mathrm{L}$ dengan pengulangan sebanyak 3 kali dari masing-masing konsentrasi yang ada untuk mendapatkan hasil yang maksimal dari sampel uji daun Mimosa pudica Linn. dan sampel uji kontrol pembanding Vitamin $\mathrm{C}$ dari hasil yang telah diperoleh pada setiap konsentrasi yang ada dengan 3 kali pengulangan hingga rata-rata hasil yang diperoleh.

Dari rata-rata hasil yang diperoleh dalam pengujian ini, sampel yang memiliki kadar aktivitas antioksidan tertinggi ditunjukkan pada konsentrasi tertinggi yaitu $100 \mathrm{mg} / \mathrm{L}$ dengan persentase hasil yang diperoleh ialah $88,38 \%$. Hal ini terlihat dari perbandingan hasil kontrol pembanding Vitamin C 100 $\mathrm{mg} / \mathrm{L}$ yang persentase hasilnya ialah $89,42 \%$. Hasil yang tidak jauh berbeda dengan hasil pada sampel uji ekstrak etanol daun Mimosa pudica Linn.

\section{PEMBAHASAN}

Tanaman yang digunakan dalam penelitian ini adalah tanaman Putri Malu (Mimosa pudica Linn.) yang diambil di Kelurahan Lahendong Kota Tomohon. Bagian tanaman yang digunakan ialah Daun. Kemudian dicuci bersih, dikeringkan dan dihaluskan menggunakan laboratorium blender. Pengeringan dilakukan untuk mengurangi kadar air yang terkandung dalam tanaman. Selain itu, proses pengeringan bertujuan pula agar sampel tidak ditumbuhi jamur selama proses penelitian. Pengeringan dilakukan dalam ruangan yang tidak terpapar sinar matahari langsung. Paparan sinar matahari langsung dihindari untuk meminimalisasi kerusakan pada sampel akibat pemanasan.

Ekstraksi dilakukan dengan cara maserasi. Cara maserasi dipilih karena bertujuan untuk menarik zat-zat yang berkhasiat yang tahan pemanasan maupun yang tidak tahan pemanasan. Proses maserasi ini dilakukan dengan beberapa kali pengocokkan atau pengadukan pada temperatur ruangan.

Penelitian ini menggunakan metode DPPH. DPPH sendiri adalah singkatan umum untuk senyawa kimia organik 2,2-difenil-1-pikrilhidrazil. Ini adalah bubuk kristal berwarna gelap yang terdiri dari molekul radikal bebas yang stabil.

Pengukuran antioksidan dengan metode DPPH pada prinsipnya adalah mengukur terjadinya pemudaran warna dari radikal DPPH akibat adanya antioksidan yang dapat menetralkan molekul radikal bebas. Jadi, radikal DPPH yang sebelumnya berwarna akan kehilangan warnanya jika ada antioksidan, karena antioksidan akan menyumbang elektronnya kepada radikal DPPH, sehingga radikal yang sebelumnya tidak stabil (akibat adanya elektron yang tidak berpasangan) menjadi stabil (elektron pada radikal bebas menjadi berpasangan karena mendapat sumbangan elektron dari antioksidan).

Pada dasarnya, karakteristik antioksidan adalah mudah untuk menyumbangkan elektron, semakin mudah 
memberikan elektron maka sifat antioksidannya semakin kuat.

Dalam penelitian ini, salah satu langkah yang dilalui ialah pembuatan larutan stok. Dalam penelitian ini, digunakan larutan stok $5 \mathrm{~mL}$. Dimana larutan stok adalah larutan yang konsentrasinya dipekatkan atau ditinggikan dari konsentrasi media.

Tujuan dari pembuatan larutan stok sendiri ialah untuk menghindari penimbangan yang berulang-ulang setiap kali membuat media. Dengan adanya larutan stok, pembuatan media selanjutnya tinggal mengencerkan larutan stok saja. Larutan stok dibuat hanya untuk satu jenis bahan. Langkah ini bertujuan untuk menghindari pengendapan larutan.

Dalam penelitian ini, dibuat 3 kali pengulangan pada setiap konsentrasi yang ada bertujuan untuk mengetahui hasil dari masing-masing konsentrasi yang ada kemudian hasil yang didapatkan tersebut akan dihitung rata-ratanya, sehingga dari hasil rata-rata tersebut dapat dilihat seberapa besar aktivitas antioksidan dalam sampel daun Mimosa pudica Linn. dibandingkan kontrol positif dari sampel vitamin C.

Vitamin $\mathrm{C}$ dipilih sebagai pembanding karena berfungsi sebagai antioksidan sekunder yaitu menangkap radikal bebas dan mencegah terjadinya reaksi berantai.

Sebelum larutan sampel Mimosa pudica Linn. dan larutan sampel Vitamin C diuji pada alat spektrofotometer UVVis, larutan sampel dan pembanding di vortex selama 2 detik. Kemudian, kedua sampel dimasukkan kedalam incubator untuk diinkubasi selama 30 menit.

2 detik dipilih karena pada saat pembuatan, larutan sudah tercampur dan sudah terlihat warna yang dihasilkan. Artinya sebelum sampel diuji, aktivitas antioksidan sudah terlihat terlebih dahulu. Untuk itu, larutan hanya di vortex selama 2 detik untuk lebih menghomogenkan larutan uji.

Dari hasil yang diperoleh pada pengujian ini, aktivitas antioksidan daun Mimosa pudica Linn. terendah terlihat pada konsentrasi $25 \mathrm{mg} / \mathrm{L}$ dengan persentase hasil ialah $84,05 \%$. Sedangakan hasil tertinggi diperoleh dari konsentrasi tertinggi yaitu $100 \mathrm{mg} / \mathrm{L}$ yang mencapai persentase hasil $88,38 \%$. Hal ini menunjukkan bahwa, semakin tinggi konsentrasi yang digunakan, maka akan semakin tinggi pula aktivitas antioksidannya. Sebaliknya, semakin rendah konsentrasi yang digunakan, maka akan semakin rendah pula aktivitas antioksidannya.

\section{KESIMPULAN}

Kesimpulan yang didapatkan dari penelitian ini ialah, ekstrak daun Mimosa pudica Linn. memiliki aktivitas antioksidan yang cukup tinggi dalam setiap konsentrasi, mulai dari konsentrasi terendah hingga tertinggi. Namun, aktivitas antioksidan tertinggi terlihat pada konsentrasi $100 \mathrm{mg} / \mathrm{L}$ yang mencapai persentase $88,38 \%$.

\section{SARAN}

Perlu dilakukan penelitian lebih lanjut tentang daun Mimosa pudica Linn. dengan menggunakan metode lain, dan membandingkan hasilnya dengan hasil yang diperoleh dari penelitian ini.

\section{DAFTAR PUSTAKA}

Atta-ur-Rahman, M.I. Choudhary. (2001).

Bioactive Natural Products a Potential 
of Pharmacophores, A Theory of Memory. Pure Appl. Chem., 73, 555560 .

Badarinath A, et al., A Review on In-vitro Antioxidant Methods : Comparisons, Correlations, and Considerations. International Journal of PharmTech Research. 2010. 1276-1285.

Fajriah, et al., 2007. Isolasi Senyawa Antioksidan dari Ekstrak Etil Asetat Daun Benalu (Dendrophthoe pentandra L. Miq) yang tumbuh pada Inang LobiLobi. Jurnal Kimia Indonesia. 2(1) : 17-20.

Gandhiraja N, Sriram S, Meenaa V. Phytochemical Screening and Antimicrobial Activity of the Plant Extracts of Mimosa pudica L. Against Selected Microbes. Ethnobotanical Leaflets. 2009; 13: 618-624.

Kuncahyo I and Sunardi. Uji Aktivitas Antioksidan Ekstrak Belimbing Wuluh (Averrhoa blimbi L) terhadap 1,1diphenyl-2-pycrilhydrazil (DPPH). Prosiding Seminar Nasional Teknologi. ISSN 1978-9997. 2007. Yogyakarta.

Marxen K, Vanselow KH, Lippemeier S, Hintze R. Determination of DPPH Radical Oxidant Caused by Methanolic Extracts of Some Microalgal Species by Linear Regression Analysis of Spectrophotometric Measurements. Sensors. 2007.

Midleton, E., Kandaswami., Theoharis. 2000. The Effect of Plant Flavonoids on Mamalian Cells: Implication for Inflammation, Heart Disease \& Cancer. Farmacological Reviews, 52(4) 711722.

Nazeema TH, Brindha V. 2009. Antihepatoxic and Antioxidant Defense Potential of Mimosa pudica.
International Journal of Drug Discovery. 2009; 1 (2): 1-4.

Prayoga G. Fraksinasi, Uji Aktivitas Antioksidan dengan Metode DPPH dan Identifikasi Golongan Senyawa Kimia dari Ekstrak Teraktif Daun Sambang Darah (Excoecaria cochinchinensis Lour). Fakultas Farmasi ProgramStudi Sarjana Ekstensi Universitas Indonesia.2013.

Rohdiana, D. (2001). Aktivitas Daya Tangkap Radikal Polifenol Dalam Daun Teh. Majalah Jurnal Indnesia, 12 (1), 53-58.

Sunarni, T. (2005). Aktivitas Antioksidan Penangkap Radikal Bebas Beberapa Kecambah dari Biji Tanaman Familia Papilionaceae. Jurnal Farmasi Indonesia (2), 53-61.

Sasikumar, J. M., Maheshu, V., Jayadev, R. (2009). In Vitro Antioxidant Activity of Methanolic Extracts of Berberis Tinctoria Lesch. Root and Root Bark. India Journal of Herbal Medicine and Toxycology, 3 (2), 53-58.

Tamilarasi T, Ananthi T. Phytochemical Analysis and Anti Microbial Activity of Mimosa pudica Linn. Res J Che Sci. 2011; 2(2): 72-74. ISSN: 2231-606X.

Trilaksani, W. (2003). Antioksidan : Jenis, Sumber, Mekanisme Kerja, dan Peran Terhadap Kesehatan. Bogor : Institut Pertanian Bogor, 1-12.

Wikipedia. Tanaman Mimosa pudica Linn. diakses 25 April 2017. Pukul 18:39. 